UDK 366.542:366.7(4-672EU)

https://doi.org/10.18485/union_pf_ccr.2021.ch21

Ágnes Horváth*

\title{
PROTECTION OF CONSUMERS PROVIDED IN THE PROPOSAL FOR A REGULATION OF MARKETS IN CRYPTO-ASSETS
}

\begin{abstract}
The paper focuses on the Proposal for a Regulation of the European Parliament and the Council on Markets in Crypto-assets and amending Directive (EU) 2019/1937. The goal of the paper is to analyze what sources of consumer protection the Proposal provides in the European Union, focusing particularly on collective consumer protection. A doctrinal legal research methodology is employed. The paper briefly presents the main points of the Proposal in regard to consumer protection and will tackle specific consumer protection rules. After analyzing what the Proposal entails as safeguards for consumer protection the paper concludes that there are mainly disclosure obligation type consumer protection measures in place, but collective consumer measures are lacking. Finally, the paper makes suggestions for a more efficient protection of European consumers.
\end{abstract}

Key words: crypto-asset, crypto-asset issuers, crypto-asset service providers, EBA, ESMA, European Union, consumer protection.

\section{INTRODUCTION}

\subsection{ON WHY THE CRYPTO-ASSET MARKET REGULATION IS A NECESSARY BUT UNGRATEFUL TASK}

The present paper is an attempt at reviewing the Proposed Regulation of the European Parliament and of the Council on Markets in Crypto-assets (hereinafter Proposal), ${ }^{1}$ a draft of the future regulation of crypto-assets in the European Union which will enter into vote in the following period. My goal is to present what consumer protection measures, especially collective consumer protection measures the Proposal provides.

The European Union and its member states have long been waiting for a Regulation for the crypto-asset markets. Blockchain based crypto-assets like

* Trainee lawyer and legal consultant currently working in Romania

e-mail: Horvath_Agnes@alumni.ceu.edu

1 Proposal for a Regulation of the European Parliament and of the Council on Markets in Crypto-assets, and amending Directive (EU) 2019/1937, COM/2020/593 (hereinafter referred to as "Proposal"). The paper discusses the version of the Proposal published on the $24^{\text {th }}$ of September 2020. 
BitCoin, Ethereum or Litecoin etc. are based on a technology that was open to anybody and relies on a distributed ledger or DLT. The question of whether the value generated in the form of crypto-assets were investment means, financial instruments, currency or some other financially or non-financially understandable assets is a problem that puzzled lawyers, economists and politicians for years, until it seems to have filtered down to a decisive undecisiveness: they can be anything - and what matters is the use they are being attributed. Since they are often used as investment tokens or even payment means, consumer protection from possible fraud or misconduct is of increased importance.

While I do recognise that the specific technical details of crypto-asset generation is of relevance for the thorough understanding of the crypto-asset market, the paper will not go into more detail on the strictly technical issues, since they do not hold direct legal consequences to the consumers and are out of the scope of the paper. Nor will this paper tackle the possible uses of crypto-assets for highly illegal activities such as money laundering or financing terrorism - which actually constitute approximately the third of all crypto-asset transactions according to some researchers. ${ }^{2}$

The focus of the paper is analyzing the safeguards provided for protecting consumers when the crypto-asset market becomes widespread enough to have substantial effect on consumers in the EU. The main problem with the crypto-asset creation market is that the value of cryptocurrencies or crypto-assets can rise and fall just like any other commodity. But unlike coffee or oil, or stocks for that matter, crypto-assets' value is not reliant on a consumable good (such as coffee or oil). Their price on the market does not reflect the demand for that commodity due to the increased need for that commodity, for example the increased demand for coffee, nor does the crypto-assets price reflect the value of the company whose stocks are being traded. ${ }^{3}$ Crypto-assets can be used for investment - due to their values increasing on demand when other investors buy them, and they can be used as payment with some service providers - at the moment the number of such service providers is quite low. ${ }^{4}$ Even if the number of merchants that accept crypto-assets as payment is still currently minimal, it will increase in the future. Due to their present speculative feature, the price of crypto-assets can rise and fall drastically from one moment to another. ${ }^{5}$ During a decline in price, millions or billions of dollars (or euros, which is more of the EU's concern) can disappear overnight and the reason for their disappearance might be completely beyond the common investor's or consumer's grasp or imagination. This fluctuation makes consumers especially vulnerable to losses and frauds.

2 Houben, R., Snyers, A., 2020, Crypto-Assets - Key Developments, Regulatory Concerns and Responses, Study for the Committee on Economic and Monetary Affairs, Policy Department for Economic, Scientific and Quality of Life Policies, European Parliament, Luxembourg, PE 648.779 , p. 8 .

3 The particular exception are the stablecoins or asset-referenced tokens crypto-assets, which are specifically tackled by the Proposal, due to their increased importance for the digital financial markets. These will be presented in more details in the first part of this paper.

4 Spending BitCoin, (https://bitcoin.org/en/spend-bitcoin, 13. 11. 2020).

5 Edwards, J., 2020, Bitcoin's Price History, Investopedia, (https://www.investopedia.com/Art.s/ forex/121815/bitcoins-price-history.asp, 13. 11. 2020). 
The Proposal reflects on the fact that some member states have already beat the curve and enacted some sort of legislation for crypto-assets: ${ }^{6}$ the German legislation which provides regulation for crypto-assets in the country has already entered into force, ${ }^{7}$ France has established optional rules ${ }^{8}$ and Malta enacted legislation in 2018 to regulate different aspects of crypto-assets. ${ }^{9}$ Regulatory fragmentation regarding crypto-assets is of major concern to the EU - with the rapidly evolving fintech sphere, especially the blockchain technology based crypto-asset development and use, member states will be forced to enact legislation in order to keep fraud and possible illegality at bay.

There is already an observable difference in handling the evolution of crypto-assets between different member states. A Hungarian example shows how Hungarian law enforcement still struggles with crypto-asset theft due to not understanding the exact nature of the crypto-assets, ${ }^{10}$ while other member states are already enacting their own crypto-market regulations. If the legislations do not match or if they even collide between the different member states, the financial and monetary common market will suffer, with some member states being highly exploited for their lenient crypto-asset regulation, while others would not be able to develop a thriving crypto-asset internal market due to the overly harsh regulatory framework. Regulatory fragmentation could thus lead to possible forum shopping at the moment of establishing one's business as a crypto-asset service provider or a crypto-asset issuer, and it can also lead to distorted competition on the common financial market of the EU, especially if other member states would follow the different models.

These are some of the consequences that the Proposal and ultimately the Regulation wants to avoid.

\subsection{ROADMAP}

In the first part I will present the definitions. I will briefly explain what the different crypto-assets are: how the asset-referenced tokens and the e-money tokens represent different subclasses of the more general crypto-assets. This review is necessary to understand the possible dangers of the different types of crypto-assets on the consumers.

In the second part I will present the main objects of the regulation, namely the crypto-asset issuers and crypto-asset service providers. I will also present the European Union authorities involved in the regulatory process, the ESMA, or the European Securities and Markets Authority and the EBA or the European

6 Proposal, p. 148.

7 Act on the Implementation of the Amendment Directive to the Fourth EU Money Laundering Directive, Entwurf eines Gesetzes zur Umsetzung der Änderungsrichtlinie zur Vierten EU-Geldwäscherichtlinie [Richtlinie (EU) 2018/843].

8 The Loi PACTE Act no. 2019-486. Official Journal, May 23, 2019.

9 Virtual Financial Assets Act, Cap. 590 of the Laws of Malta, 2018.

10 Tajti, T., Fintech Regulation in Hungary, in: Cian, M., Sandei, C. (eds.), 2020, Diritto del Fintech. $1^{\text {st }}$ ed. Milano, Wolters Kluwer Italy - CEDAM, p. 618. 
Banking Authority. Presenting the issuers and service providers helps us in understanding the type of activity that can represent dangers for the consumers.

The third part will dive into the consumer protection measures provided in the Proposal, with a specific goal of uncovering collective forms of protection. It will tackle the crypto-asset white paper obligations, the right of withdrawal, the complaint handling procedure, rules on conflicts of interest and insider dealing and market manipulation handling methods.

The last part will draw the paper's conclusions and will address possible suggestions of improvement for the final Regulation.

\section{DEFINING CRYPTO-ASSETS. WHAT IS BEING REGULATED?}

The Proposal puts forward definitions for distributed ledger technology, crypto-assets, asset-referenced tokens, electronic money tokens, utility tokens, issuers of crypto-assets, crypto-asset service provider, crypto-asset services, competent authorities and consumers in the context of crypto-assets. ${ }^{11}$ These definitions are surprisingly broad. Distributed ledger technology or 'DLT' is "a type of technology that supports the distributed recording of encrypted data". ${ }^{12}$ The definition does not go into technical details or demand a certain type of legal subject to qualify as the creator of the data gathering technology or the ledger itself. Similarly, crypto-assets are defined as "a digital representation of value or rights which may be transferred and stored electronically, using distributed ledger technology or similar technology". ${ }^{13}$

The Proposal has chosen to provide a baseline regulation for the general regime of crypto-assets and exceptional regime for the specific crypto-asset types (asset-referenced tokens and e-money tokens). The increased specificity is evidenced as asset-referenced tokens, electronic money tokens and utility tokens, which are all types of crypto-assets categorized under the regulatory framework of the Proposal. To analyze them separately:

\subsection{ASSET REFERENCED TOKENS}

Asset referenced tokens are defined by the Proposal as "a type of crypto-asset that purports to maintain a stable value by referring to the value of several fiat currencies that are legal tender, one or several commodities or one or several crypto-assets, or a combination of such assets". ${ }^{14}$ These crypto-assets are anchored or referenced to other assets, such as fiat currencies that are legal tender, for example the euro, to different types of commodities, like gold or silver, one or several crypto-assets, like Bitcoin or Ethereum, or a combination of these assets. Asset-referenced tokens, unlike other crypto-assets that are not anchored in value

11 Art. 3 of the Proposal.

12 Art. 3 (1) of the Proposal.

13 Art. 3(2) of the Proposal.

14 Art. 3(3) of the Proposal. 
to any other asset, have the potential of becoming even more widely used, due particularly to the fact that they are based on an outside value which can make them more stable - that is why they are also called stable coins. ${ }^{15}$

While they do offer a more stable value preservation for the crypto-assets, they also have the potential to represent bigger dangers than others due to their widespread use. With that in mind, it was established in the Context of the Proposal - Reasons for and objectives of the proposal section that " $\mathrm{t}]_{\mathrm{o}}$ respond to all of these issues and create an EU framework that both enables markets in crypto-assets as well as the tokenization of traditional financial assets and wider use of DLT in financial services, this Regulation will be accompanied by other legislative proposals"16. As a matter of fact, tokenization has benefited from increased interest in recent years: the OECD has put together a document on the tokenization of assets, precisely because of their importance for the future of financial markets. ${ }^{17}$ Consumers would be able to use asset-referenced tokens for investment purposes. The Proposal does not specify whether these can be used for payment or whether they are intended to be used for payment, unlike the so called e-money tokens below. This lack of specification regarding the use of the asset-referenced tokens for payment purposes, but the definitively intended use of e-money tokens as means of payment suggests an important difference between the two types of special crypto-assets: asset-referenced tokens are not meant to be used as means of exchange or as a type of currency, while e-money tokens are designated by the Proposal for those exact purposes.

\subsubsection{Significant asset-referenced tokens and e-money tokens}

There is an important subclass of asset referenced tokens, the significant asset-referenced tokens which fulfill at least 3 of the criteria mentioned in Article 39(1): they are significant due to the size of the customer base of the promoters of the asset-referenced tokens, the shareholders of the issuer or of any of the third-party entities; the value, the number and value of transactions in those asset-referenced tokens, the size of the reserve of assets of the issuer of the asset-referenced tokens; the significance of the cross-border activities of the issuer of the asset-referenced tokens, including the number of member states where the asset-referenced tokens are used, the use of the asset-referenced tokens for cross-border payments and remittances and the number of member states where the third-party entities are established; or there is interconnectedness with the financial system. ${ }^{18}$ Issuers can also voluntarily apply for the classification of the asset-referenced tokens as significant. ${ }^{19}$

15 Hayes, A. Stablecoin, Investopedia, (https://www.investopedia.com/terms/s/stablecoin.asp, 14. 11. 2020).

16 Explanatory Memorandum, Context of the Proposal, p. 2.

17 OECD, 2020, The Tokenisation of Assets and Potential Implications for Financial Markets, OECD Blockchain Policy Series, (www.oecd.org/finance/The-Tokenisation-of-Assets-andPotentialImplications-for-Financial-Markets.html, 13. 11. 2020).

18 Art. 39(1) of the Proposal.

19 Art. 40(1) of the Proposal. 
While significant asset-referenced tokens clearly represent a higher risk profile, the Proposal does require different risk avoidance measures. The Proposal requires issuers to "adopt, implement and maintain a remuneration policy that promotes sound and effective risk management of such issuers and that does not create incentives to relax risk standards." 20 The Proposal also requires that such issuers not rely on the same service providers as for other asset-referenced tokens who do not belong to the same group. ${ }^{21}$ The separation of service providers based on the significance of the asset-referenced tokens involved is helpful in protecting the holders of the non-significant asset referenced tokens from the dangers that can fall on holders of significant asset-referenced tokens, while also providing a more increased protection to holders of significant asset-referenced tokens, in theory.

There are identical requirements established for significant e-money tokens, ${ }^{22}$ which can also be claimed voluntarily in similar conditions to the asset-referenced tokens. ${ }^{23}$

\subsection{ELECTRONIC MONEY TOKENS OR E-MONEY TOKENS}

Electronic money token or 'e-money token' are a "type of crypto-asset the main purpose of which is to be used as a means of exchange and that purports to maintain a stable value by referring to the value of a fiat currency that is legal tender" ${ }^{24} \mathrm{E}$-money tokens are similar to asset-referenced tokens in that they have a value stabilized by a legal tender that is a fiat currency but the important difference is that these are meant to be used as a means of exchange and they can only refer to currencies. Thus, an e-money token is a close cousin with the above subtype of crypto-assets. Since e-money tokens are used as a means of exchange, such as payment for goods and services in place of money - possibly to any vendor that will accept them, their possible effect on the European markets is widespread and consumers will require special protective measures to face the dangers entailed.

\subsection{UTILITY TOKENS}

Utility tokens are a subtype of crypto-asset with different scope and use than the above. ${ }^{25}$ It is intended to provide digital access to goods or services on the distributed ledger and is only accepted by the issuer of that token for those specific purposes. ${ }^{26}$ These type of crypto-assets are used as payment, similarly

20 Art. 41(1) of the Proposal.

21 Art. 41(2) of the Proposal.

22 Art. 50 of the Proposal.

23 Art. 51 of the Proposal.

24 Art. 3(4) of the Proposal.

25 Sharma, T. K., 2019, Security Tokens vs. Utility Tokens : A Concise Guide, Blockchain Council, (https://www.blockchain-council.org/blockchain/security-tokens-vs-utility-tokens-a-concise-guide/, 12. 11. 2020).

26 Art. 3(5) of the Proposal. 
to the e-money tokens, but they are only accepted by their own issuers, most probably during exchanges specified by the issuer, on the DLT. Their use is very limited, which gives them a lower level of danger when it comes to consumer protection concerns and will not be thoroughly analyzed in this paper.

\subsection{THE DIGITAL EURO}

The European Central Bank (hereinafter: ECB) has raised the idea that a digital euro ${ }^{27}$ would be beneficial for citizens of the euro area and of the EU, since payment habits of consumers in the region have shifted to contactless payment methods due to a fear of contacting diseases and viruses, such as Covid-19. The idea of issuing such currency is not necessarily a completely new one: similar projects are the so called central bank digital currencies or CBDC-s. The latter are generally considered to be crypto-assets based on DLT technology, while the digital euro will not be construed as a crypto-asset. As a matter of fact, the report states that "[t]he digital euro would be a risk-free form of central bank money" 28 and not a crypto-asset which formulation does imply that crypto-assets are not risk free.

While it is obvious that the ECB would not issue any digital currency on a decentralized distributed ledger, it is not quite clear whether there would be other security safeguards that would differentiate the possible digital euro from other crypto-assets (or asset-referenced tokens) that rely on a freely available DLT. Having a digital euro that is administered by the Euro system and the ECB is a development that the whole European continent would welcome. It could provide a faster and easier access to the common currency than merely cash payments. But the technology needs to be secure enough not to jeopardize the common currency - a consideration that the ECB does not dismiss. ${ }^{29}$

\section{WHO IS BEING REGULATED AND WHAT ARE THEY DOING? WHO ARE CRYPTO-ASSET ISSUERS AND CRYPTO-ASSET SERVICE PROVIDERS? WHAT IS ESMA AND EBA?}

The legal and natural persons regulated under the Proposal are issuers and service providers, and the authorities which have regulatory and supervisory powers over them. Issuers are the economic agents who either issue the crypto-assets (be those generic crypto-assets, asset-referenced tokens, e-money tokens or utility tokens) or who provide different services regarding different crypto-assets.

27 ECB, 2020, Report on a Digital Euro 55 October 2020, (https://www.ecb.europa.eu/pub/pdf/ other/Report_on_a_digital_euro 4d7268b458.en.pdf, 13. 11. 2020).

28 Ibid., p. 50.

29 Ibid., p. 20. 


\subsection{CRYPTO-ASSET ISSUERS}

A crypto-asset issuer is defined as "a legal person who offers to the public any type of crypto-assets or seeks the admission of such crypto-assets to a trading platform for crypto-assets" 30 , meaning that it does not have to be the originator or the creator of the crypto-asset itself. Thus, issuing can either take the form of offering to the public or circulating or trading the crypto-asset on trading platforms. The Proposal requires all issuers to be legal entities, to draft, notify and publish a crypto-asset white paper (which will be discussed later in the paper) and to comply with issuer specific duties to be compliant and to be able to offer or seek admission on a trading platform of crypto-assets - all this unless they wish to issue asset-referenced tokens or e-money tokens. ${ }^{31}$ Through this provision the Proposal established a regulatory and compliance divide between issuers of asset-referenced tokens and e-money tokens on one side, and between issuers of other type of crypto-assets on the other. Consequently the obligations of the issuers differ.

The obligations of issuers of crypto-assets, other than asset-referenced tokens or e-money tokens are the following (vaguely defined) obligations, ${ }^{32}$ to act honestly, fairly and professionally (a thoroughly vague and non-descript obligation allowing for vast legal and judicial debate on what constitutes honest, fair and professional), to communicate with the holders of crypto-assets in a fair, clear and not misleading manner (also a great candidate for confusing legal debates), to prevent, identify, manage and disclose any conflicts of interest that may arise, and to maintain all of their systems and security access protocols to appropriate Union standards (that will be established by the ESMA and the EBA in the future). ${ }^{33}$ There is also a duty of equal treatment toward the holders of crypto-assets (other than asset-referenced tokens and e-money tokens), ${ }^{34}$ and an obligation to return to purchasers or potential purchasers of any funds collected in case of a cancellation of the issuance. ${ }^{35}$ These duties are more of general common sense commercial duties with little tangible applicability - their deeper scope and applicability will probably be defined by the courts and most probably by the Court of Justice of the European Union (hereinafter CJEU).

While the issuers of crypto-assets other than asset-referenced tokens or e-money tokens only need to be legal entities with registration even outside of the EU, the issuers of asset referenced tokens ${ }^{36}$ and e-money tokens ${ }^{37}$ have the obligation to seek authorization from the competent authority of their home

30 Art. 3(6) of the Proposal.

31 Art. 4 of the Proposal.

32 Art. 13 of the Proposal.

33 Art. 13 of the Proposal.

34 Art. 13 point 2 of the Proposal.

35 Art. 13 point 3 of the Proposal.

36 Art. 15(1) of the Proposal.

37 Art. 43(1) of the Proposal. 
member state. The "home member state" can be a wide category, the Proposal offers the following criteria for pointing to the home member state: where the issuer has a registered office or a branch, where, if it has no registered office in the EU but has two branches, then whichever branch it chooses, if it has no registered office or branch in the EU, but only in a third country, where the crypto-assets are intended to be offered to the public, for issuers of asset-referenced tokens and crypto-asset service providers as well, the member state where it has a registered office, and, lastly, for issuers of e-money tokens, where it is authorized as a credit institution. ${ }^{38}$ It should be highlighted that due to the heightened danger that asset-referenced tokens, service providers and e-money tokens represent toward European consumers, the home member state which will house the competent authority supervising the activity of the issuers or service providers can only be where these entities have their registered office. It is prevalent from this legislative measure as well, that crypto-asset issuers, other than asset-referenced tokens and e-money tokens, are not considered to be particularly of peril to the European consumers and the common market. This authorization will be valid for the whole union via passporting. The authorization can be granted, refused, withdrawn by the competent authority. This measure provides an increased supervisory power for the issuers of asset referenced tokens and e-money tokens, while issuers who do not issue these two types of crypto-assets do not have to comply with additional authorization requirements.

Asset referenced tokens can only be issued with white papers that comply with the requirements for all crypto-assets, and additional requirements, such as a description of the issuers governance arrangements, a description of the reserve of assets, custody arrangements and investment policy for the reserve of assets, information on the nature and enforceability of rights, for example the rights of direct redemption on the reserve assets, including the treatment of these rights during insolvency proceedings, information on the measures taken by the issuer to ensure liquidity of the asset referenced tokens, information on the complaint handling procedure. ${ }^{39}$ Issuers of asset referenced tokens have an ongoing information obligation toward the holders of their asset referenced tokens to disclose on their website what the amount of asset referenced tokens is in circulation and the value of their reserve assets. ${ }^{40}$ Reserve assets enjoy special protection due to their importance for stabilizing the value of the tokens. The thorough supervision of the reserve of assets is of vital importance for the protection of consumers.

The reserve of assets is supposed to reflect the asset-referenced tokens that the issuer issues - thus, if asset-referenced tokens are created or destroyed these measures are "matched" by the reserve of assets as well. ${ }^{41}$ The reserve of assets is created with the idea to contribute to the stabilization mechanism of the asset-referenced tokens, thus it is vital that the reserve of assets is permanently

38 Art. 4(22) a)-f) of the Proposal.

39 Art. 17(1) of the Proposal.

40 Art. 26 of the Proposal.

41 Art. 32(2) of the Proposal. 
matched by the reserves. A stabilization policy describing the mechanism must be put in place by the issuer. ${ }^{42}$ In order to avoid any possible commingling of assets, the issuers of asset referenced tokens are responsible for establishing custody policies for the reserve of assets, in order to keep these assets separate from the issuer's own. This ensures that the assets in the reserve are not "not encumbered nor pledged as a 'financial collateral arrangement', a 'title transfer financial collateral arrangement' or as a 'security financial collateral arrangement' [...]"43 and to make sure that they have prompt access to the reserve of assets in order to meet possible redemption requests by the consumers.

Another obligation applicable only to asset-referenced token issuers is to have "own funds" in the minimum amount of 350,000 euros or $2 \%$ of the average amount of the reserve assets. ${ }^{44}$ This is a safeguard of prudential nature, which is put in place to make sure that the issuers have sufficient funds to withstand possible turmoil that can have an effect on the holders of asset-referenced tokens.

On the other hand, e-money tokens are in the particular situation that their authorization has to be as a credit institution or an electronic money institution in order for it to be compliant, ${ }^{45}$ also, it has the obligation to publish a white paper notified to the competent authority. ${ }^{46}$

\subsection{CRYPTO-ASSET SERVICE PROVIDERS}

Crypto-asset service providers are "any person whose occupation or business is the provision of one or more crypto-asset services to third parties on a professional basis" 47 and that have a registered office in one of the member states. ${ }^{48}$ This definition is vague, but it allows for the services themselves to be listed and defined in a more precise manner. The services are:

The custody and administration of crypto-assets on behalf of third parties, ${ }^{49}$ this entails custody of crypto-assets or the means of access to such crypto-assets in the form of private cryptographic keys. ${ }^{50}$ This represents a purely custodian function in order to safely keep the crypto-assets without bringing any additional services, like the ones below.

The operation of a trading platform for crypto-assets, ${ }^{51}$ within which multiple third-party buying and selling interests for crypto-assets can interact by exchanging one crypto-asset for another or for a fiat currency that is legal tender. ${ }^{52}$

42 Art. 32 (4) of the Proposal.

43 Art. 33(1) b) of the Proposal.

44 Art. 31 of the Proposal.

45 Art. 43(1) a) of the Proposal.

46 Art. 43 of the Proposal.

47 Art. 3(8) of the Proposal.

48 Art. 53(1) of the Proposal.

49 Art. 3(9) a) of the Proposal.

50 Art. 3(10) of the Proposal.

51 Art. 3(9) b) of the Proposal.

52 Art. 3(11) of the Proposal. 
This is imagined similarly to a trading floor on a stock-exchange, for other crypto-assets or currencies. Due to its possibility to exchange for other crypto-assets, this service has the potential to serve investment purposes. Trading can be exchanging crypto-assets for fiat currency, ${ }^{53}$ or for other crypto-assets. ${ }^{54}$ These are generally seen as exchange or trading functions, similarly to stock-exchanges for stocks or other securities.

Service providers can provide advice on crypto-assets. ${ }^{55}$ This service would closely resemble investment advisory services with the specific scope of advising on crypto-asset purchase or other type of investment opportunities relating to crypto-assets. It is not quite clear how service providers would be penalized for not giving appropriate or sound advice, whether there would be a difference from other type of investment advisory activities or not. It is certain that the Proposal requires advisors to assess the level of knowledge of the customers and to write a report about the customer's needs. ${ }^{56}$

Even though the list about possible services that can be provided is long, this is a closed list, and, while we can praise the Proposal for being forward looking in keeping the definition of crypto-assets and their types relatively open, the fact that the services defined by the Proposal make up a closed list, can lead innovative de facto crypto-asset service providers to escape the regulation and thus, escape liability. In order to better protect consumers from possible fraud by service providers, supervisory authorities need to be especially vigilant for suspicious activity that might not be included into the list about the possible service provided in the Proposal. Additionally, service providers must have prudential safeguards in the form of own funds of significant value and an insurance policy for all jurisdictions where services are provided. ${ }^{57}$

\subsection{AUTHORITIES}

The two primary European Union authorities in charge of regulating issuers and service providers are the ESMA ${ }^{58}$ and the EBA. ${ }^{59}$ Additionally, competent authorities of the member states where issuers or service providers pursue their activity will also be established as a first point of contact for possible infringement of the future MiCA regulation.

The involvement of ESMA suggests that crypto-asset regulation needs to be handled similarly to securities regulation, this can be due to their investment and due to the fact that they will have effect on the monetary market in Europe.

53 Art. 3(9) c) of the Proposal.

54 Art. 3(9) d) of the Proposal.

55 Art. 3(9) h) of the Proposal.

56 Art. 73(7) of the Proposal.

57 Art. 60(2) a)-b) of the Proposal.

58 ESMA, Who we are, (https://www.esma.europa.eu/about-esma/who-we-are, 12. 11. 2020).

59 European Banking Authority, 2016, European Union, (https://europa.eu/european-union/ about-eu/agencies/eba_en, 12.11.2020). 
ESMA handles the register for crypto-asset service providers ${ }^{60}$ while the EBA has a supervisory role over issuers of significant asset-referenced tokens and e-money tokens ${ }^{61}$ and it has general investigative powers that it can use when needed. ${ }^{62}$ It is also the EBA that can conduct on-site inspections, ${ }^{63}$ and it can impose fines ${ }^{64}$ and periodic penalty payments. ${ }^{65}$ The Proposal suggests on multiple occasions that the two European authorities will be working together to fine-tune the details of the Regulation which are not precisely provided in the Proposal form yet.

On the European level the fines or penalties imposed by the EU authorities can be reviewed by the CJEU, which has unlimited jurisdiction over the complaints in matters regarding crypto-assets. ${ }^{66}$

As a first step in providing protection to consumers within their geographical boundaries, the member states will be obligated to establish responsible authorities that would oversee the issuers of asset-referenced tokens and e-money tokens.

\section{HOW ARE CONSUMERS PROTECTED?}

This part analyzes the main consumer protection methods mentioned by the Proposal and highlights their effectiveness or how they lack in effectively protecting consumers. The main issues discussed will be the white paper obligations, the right of withdrawal, complaint handling procedures, rules on conflict, insider dealing and market manipulation together with two popular fraudulent practices, the pump and dump and Ponzi schemes.

Crypto-assets, whether they are used for investment purposes or meant to be used as payment, rely on their value being established via their use by a bigger and bigger community of holders, who purchase, use or trade them. The bigger the pool of consumers that hold the given crypto-asset, the bigger the value or price or influence of that crypto-asset will be. While individual crypto-asset holders will be able to action crypto-asset issuers or service providers for their infringements, collective redress possibilities need to be granted to the community of crypto-asset holders who suffer damages.

The reason why collective measures are especially vital, aside from the fact that the overall structure of the crypto-asset markets rely heavily on a large community of consumers, is due to the fact that the wealth that issuers or service providers can make from fraud regarding crypto-assets can be quite a lot. ${ }^{67}$ If

60 Art. 57(1) of the Proposal.

61 Art. 98 of the Proposal.

62 Art. 105 of the Proposal.

63 Art. 106 of the Proposal.

64 Art. 113 of the Proposal.

65 Art. 114 of the Proposal.

66 Art. 118 of the Proposal.

67 INCE Group, 2020, Cryptoassets - Believing the money laundering impact, (https://www.incegd.com/en/news-insights/cryptoassets-believing-money-laundering-impact, 11. 11. 20). 
left to the legal actions of the individual consumer, the sanctions applied by the courts following a lost court case initiated by the individual crypto asset holder might not amount to even approach the level of the wealth that the fraud itself has generated. Fraudulent practices, such as pump and dump, can generate massive amounts of wealth for the fraudsters, while possibly only implying modest amounts of losses for the individual consumers. If courts assess the damages based on the individual consumer's losses, the amount of the sanction will not be nearly as much as the amount that the fraud itself is able to enrich the fraudster. Even if combined with jail sentences or other administrative measures, if the gains are incomparably higher than the penalties issuers or service providers will feel encouraged to turn to fraudulent measures again and again.

Considering the overall wins that fraud can bring, it would be advised that collective consumer protection measures be implemented in order to ensure the deterrent effect of the sanction. If a synchronized action involving more complainants can be brought against the alleged wrongdoer, it is more probable that the damages will be more substantive and will have a deterrent effect for the future.

In the United States of America it is already established practice that consumers wronged by crypto companies rely on the possibility of enforcing their rights via class-actions. ${ }^{68}$ If the European legislator wants to keep the European citizens safe from possible wide reaching financial harm, collective consumer protection measures should be the cornerstone of consumer protection when it comes to crypto-assets.

The main methods the Proposal suggests are sanctions and fines imposed by the competent authorities. Host member states must notify the competent authority of the home member state and ESMA about irregularities committed by issuers and service providers and for issues relating to asset-referenced tokens or e-money tokens it will also notify the EBA. ${ }^{69}$

The issue is that while the sanctions can seem adequate, if imposed as singular penalties, the sanctioned entities will not be deterred from future wrongdoing, due to the high level of economic gains that can be made from crypto-assets. In order to truly protect consumers collective measures need to become the norm. There is currently a directive in works about the representative collective consumer protection..$^{70}$ Unfortunately, since the legislation regarding representative collective measures will have a directive form, the member states will be allowed to diverge in some respects from each other. In order to ensure that consumers can protect their rights collectively it would be advised that the final form of the Regulation of MiCA reflect on possible collective consumer protection measures.

68 Jamie Redman, 2020, ICO Crackdown, 11 Class-Action Lawsuits Filed Against Cryptocurrency Companies, Bitcoin News, (https://news.bitcoin.com/ico-crackdown-11-class-action-lawsuits-filed-against-cryptocurrency-companies/, 11. 11. 2020).

69 Art. 89(1) of the Proposal.

70 Proposal for a Directive of the European Parliament and of the Council on the representative actions for the protection of the collective interests of consumers, and repealing Directive 2009/22/EC COM/2018/0184 final - 2018/089 (COD) EUR-Lex - 52018PC0184 - EN EUR-Lex. 


\subsection{CRYPTO-ASSET WHITE PAPERS}

One of the disclosure measures for consumer protection are the mandatory publication of crypto-asset white papers. Crypto-asset white papers fulfill a similar function to a prospectus regarding the issuance of stocks. They are meant to present in a fair, clear and not misleading way (a vague terminology once again) a large amount of information about the crypto-asset issued, including the dangers that can arise in relation to the crypto-assets, and even about the issuer itself. More precisely, the Proposal mentions that the white papers should include information about the detailed descriptions of the issuer and the main participants involved in the project's design and development, the project itself, the type of crypto-asset in question, the reasons why the crypto-assets will be offered to the public, the planned use of the fiat currency or other crypto-assets collected via the offer to the public, a detailed description of the characteristics of the offer to the public, like the number of crypto-assets, the issue price of the crypto-assets and the subscription terms and conditions, a detailed description of the rights and obligations attached to the crypto-assets and the procedures and conditions for exercising those rights, information on the underlying technology and standards applied by the issuer of the crypto-assets allowing for the holding, storing and transfer of those crypto-assets, a detailed description of the risks relating to the issuer of the crypto-assets, the crypto-assets, the offer to the public of the crypto-asset and the implementation of the project and other disclosure items. ${ }^{71}$

This list is long, and it is quite obvious that the European legislator means to capture all possible piece of information that can be subject of disclosure for the benefit of consumers. The information provided for the consumers seems to be overly technical at some instances. Providing information on the technology applied for the issuance seems like flooding the consumers with unintelligible technologist terms which will end up not be consulted. Nevertheless, this information is necessary for cases of security or technology breaches. Disclosure in itself might seem to lack in efficiency, since simply disclosing information will not mean that consumers will thoroughly grasp the dangers involved in crypto-assets. In addition to the probability of disclosure in itself be ineffective, the white papers will also include a statement meant to catch the eye of consumers and make them especially vigilant: "The issuer of the crypto-assets is solely responsible for the content of this crypto-asset white paper. This crypto-asset white paper has not been reviewed or approved by any competent authority in any Member State of the European Union." 72

Placing the main duty of vigilance on the consumers can be a perilous strategy, especially when financial market misconducts are the subject. White papers are only the first step in informing the consumers about the crypto-assets and the issuer, but they need to be complemented with other, more effective consumer protection measures.

71 Art. 5(1) a-g) of the Proposal.

72 Art. 5(3) of the Proposal. 
The white paper is not allowed to contain any assertions on the future value of the crypto-assets, only if the issuer can guarantee such future value - which seems like a promise that issuers cannot keep and will be required to put up significant securities in case of a decline in value. It must contain a clear and unambiguous statement regarding possible changes in value and liquidity or transferability, with a special regard to the particularities of utility tokens, which might not be exchangeable. ${ }^{73}$

The obligations regarding the crypto-asset white papers are not applicable when the crypto-assets are offered for free, the crypto-assets are automatically created through mining as a reward for the maintenance of the DLT or the validation of transactions, the crypto-assets are unique and not fungible with other type of crypto-assets, the crypto-assets are offered to fewer than 150 natural or legal persons per member state where such persons are acting on their own account. ${ }^{74}$ Also, white papers are not needed for issuing crypto-assets over a period of 12 months, if the total consideration of an offer to the public of crypto-assets in the EU does not exceed 1,000,000 euros, or the equivalent amount in another currency or in crypto-assets or the offer to the public of the crypto-assets is solely addressed to qualified investors. ${ }^{75}$

This exception is surprisingly permissive for issuers of crypto-assets, who do not issue asset-referenced tokens or e-money tokens, even if one if their single offer approximates to 1 million euros - which can still represent danger to numerous consumers. These issuers do not have to draft a white paper, notify the competent authorities or publish the white paper - thus they can issue crypto-assets offered at below 1,000,000 euros or to a pool of maximum 150 citizens without a white paper being published or presented to the competent authorities. Even though the dangers represented by crypto-asset issuers, who do not issue asset-referenced tokens or e-money tokens seem to be perceived as lower by the EU Proposal's legislator, it could still carry considerable risk for the European consumers. This step shows that crypto-assets (other than asset-referenced tokens or e-money tokens) are not considered to be similar in representing danger to consumers as securities would be, unless they reach a certain threshold of 1 million euros or 151 holders - because for the benefit of consumers the securities EU Regulation requires the publication of the prospectus when offered to the public or admitted to trading. ${ }^{76}$

The white papers do not have to be approved by competent authorities ex ante, which makes their publication and the notification obligation apparently superfluous. ${ }^{77}$ The lack of an approval obligation is understandable from a logistical and economical point of view: approving every single white paper would

73 Art. 5(5) of the Proposal.

74 Art. 4(2) a-f) of the Proposal.

75 Ibid.

76 Regulation (EU) 2017/1129 of the European Parliament and of the Council of 14 June 2017 on the prospectus to be published when securities are offered to the public or admitted to trading on a regulated market, and repealing Directive 2003/71/EC.

77 Art. 7(1) of the Proposal. 
be inefficient for the competent authorities who would not be able to process all the white papers submitted by issuers. This would be especially true if the task would be undertaken by the same authorities who are otherwise responsible for overseeing the activities of issuers and service provider. But there is also a major downside to neglecting ex ante approval. The lack of this approval suggests that the EU employs a strategy based on ex post action against non-compliant issuers, subjecting consumers who were wronged to the decision of courts and regulatory authorities.

The member state's competent authority is only supposed to be notified before publication of the white paper, but it does not have the obligation to analyze the contents of the white paper. The notification must contain arguments why the crypto-assets are not financial instruments, electronic money, deposits or structured deposits, ${ }^{78}$ and this information could either be correct or misleading, the competent authorities will not find out until consumers complain about misconduct. After notification the member state's competent authorities might (if they consider) resort to their supervisory and investigative powers which are to require information, suspend or prohibit provision of crypto-assets for 10 days, to require the issuers to make public the fact of non-compliance. ${ }^{79}$ These are quite probably some hardly deterrent measures for future non-compliance and an ex post investigation is much more probable than a proactive approach from the competent authority.

The issuers have specific liability for providing misleading information or information that is not complete, fair or clear (obscure notions used once again) ${ }^{80}$ The holder of crypto-assets may claim damages from the issuer (the legal person) or its management body. ${ }^{81}$ Consequently, the holder must show that infringement of the information obligation in the white paper took place and that this infringement led the consumer to purchase the crypto-assets. ${ }^{82}$ The burden of proof is thus upon the consumer for proving that the information obligation of the issuer about conveying very difficult technological and financial information successfully to the layman consumer. This type of burden of proof in itself, for the isolated individual consumer might have a deterrent effect from initiating and following through with legal proceedings. If the consumer is isolated in his or her endeavor to prove the infringement it is quite possible that they will be discouraged from doing so.

But unlike the full misinformation in the white paper, the consumers will not be able to claim damages from misinformation in the summary, only if the summary is misleading, inaccurate or inconsistent (these notions can be subject of vast interpretations in court) when read together with the other parts of the crypto-asset white paper, or the summary does not provide key information that would help consumers and investors when considering whether to buy cryp-

78 Art. 7(3) of the Proposal.

79 Art. 82(1) of the Proposal.

80 Art. 14 of the Proposal.

81 Art. 14(1) of the Proposal.

82 Art. 14(2) of the Proposal. 
to-assets. ${ }^{83}$ Since this is a separate subsection of the article, in lack of a reference to the duty of the consumer to prove the purchase was made due to the misinformation in the summary, we cannot assume that this duty persists even in the case of the misinformation in the summary.

The Proposal does not exclude civil liability in accordance with national law either. ${ }^{84}$ Exclusion of civil liability, for example contractually, is devoid of legal effect in case of all three type of crypto assets mentioned in the Proposal. The Proposal does not specify whether this would be the issuer's home member state or the consumer's home member state if the two are different. Without an exact reference to this, my can only assume that the consumers will be protected in their home state jurisdiction and will have a cause of action in their own home MS, similarly to other EU level regulations. ${ }^{85}$

Aside from the white papers, all issuers are allowed to publish marketing communications if these are clearly identifiable as such, are fair and not misleading, and if they do not contradict the white paper and clearly state the existence of a white paper and where that can be found. ${ }^{86}$ Marketing communications need to be notified to the competent authorities together with the white papers. In case of asset reference tokens, the marketing publications must contain a clear and unambiguous statement that all the holders of the asset-referenced tokens do not have a claim on the reserve assets or cannot redeem those reserve assets with the issuer at any time, in case no direct claim or redemption right has been granted to all the holders of asset-referenced tokens. ${ }^{87}$ This is another disclosure obligation that in itself might seem inefficient, thus additional safeguards are necessary to improve the protective measures.

Requirements for the white paper regarding e-money tokens does not represent particularities in comparison with asset-referenced tokens or crypto-asset issuers. Also, the liability for misinformation in white papers to asset referenced tokens or e-money tokens is not different than that of crypto-assets, even though asset referenced tokens and e-money tokens are treated more serenely throughout the whole Proposal.

White papers are generally meant as disclosure measures, and as such the white papers themselves will not be investigated ex ante. Competent authorities will be able to take appropriate administrative measures for infringements regarding white papers. ${ }^{88}$ The pecuniary sanction available for infringement of white paper related obligations being "at least twice the amount of the profits gained or losses avoided because of the infringement where those can be determined"89

83 Art. 14(3) a) and b) of the Proposal.

84 Art. 14(4) of the Proposal.

85 Regulation (EU) 1215/2012 of the European Parliament and of the Council on jurisdiction and the recognition and enforcement of judgments in civil and commercial matters (recast) (Recast Brussels Regulation) Art. 18.

86 Art. 6 of the Proposal.

87 Art. 25(2) of the Proposal.

88 Art. 92(1) a) of the Proposal.

89 Art. 92(2) c) of the Proposal. 
is clear that the Proposal suggests that their determination would not always be possible, and for those situations the maximum sanctions are 5 million euros or $3 \%$ annual turnover ${ }^{90}$ for legal persons and 700,000 euro for natural persons. ${ }^{91}$ The problem with structuring the sanctions in this manner is that competent authorities might not feel encouraged to enforce the issuers' white paper duties unless the wronged consumers will firstly engage issuers' liability in court proceedings. It would be beneficial if competent authorities, upon becoming cognizant of white paper obligation infringement, inform consumers about their possibility of suing the issuers for their liability in court in a collective manner.

On a national level, competent authorities can impose administrative sanctions and measures against infringements. ${ }^{92}$ Penalties or fines can be 5 million euros or $3 \%$ of the total annual turnover for legal persons ${ }^{93}$ and 700,000 euros for natural persons in case of issuers other than asset-referenced or e-money tokens, ${ }^{94}$ maximum pecuniary sanctions of $15 \%$ of the annual turnover for legal person issuers of asset-referenced tokens. ${ }^{95}$ It is the member state's prerogative to provide for a possible access to court in the form of an appeal at a tribunal in case of all decisions. ${ }^{96}$ This right to appeal will be a formality as long as the judges who hear the appeal are not properly educated about the complex issues of crypto-assets and financial law.

\subsection{RIGHT OF WITHDRAWAL}

An important right provided by the Proposal is the right of the consumer to withdraw their agreement within 14 days agreeing to purchase the crypto-assets, other than asset-referenced tokens and e-money tokens, without incurring any cost or giving any reasons for the withdrawa ${ }^{97}$ and the issuer must inform the consumers about this right in the white paper. ${ }^{98}$ While the first 14 days are protected from any sanctions for withdrawing from the agreement, the Proposal does not precisely prohibit withdrawal later on - thus, it is possible that with contractually agreed costs, the consumers might be able to withdraw their consent. This is a flaw in the Proposal, and it should be remediated in the final Regulation. The reimbursement has to be provided without delay in 14 days after being informed about the consumer's decision to withdraw and it will be carried out in the same means of payment. ${ }^{99}$

As an important, and understandable measure, the right of withdrawal shall not be granted if the crypto-assets are admitted to trading on a trading platform

90 Art. 92(2) d) of the Proposal.

91 Art. 92(2) e) of the Proposal.

92 Art. 92(1) of the Proposal.

93 Art. 92(2) d) of the Proposal.

94 Art. 92(2) e) of the Proposal.

95 Art. 92(3) of the Proposal.

96 Art. 94 of the Proposal.

97 Art. 12(1) of the Proposal.

98 Art. 12(3) of the Proposal.

99 Art. 12(2) of the Proposal. 
for crypto-assets, ${ }^{100}$ or after the time period for subscription has elapsed. ${ }^{101}$ The white papers must contain the fact that the crypto-assets will be traded ${ }^{102}$ and any modifications of the white paper need to be published, including intentions of trading of the crypto-asset. As an important safeguard, the Proposal establishes the responsibility that the competent authorities need to be informed 7 working days in advance of the publication of the modified white paper. ${ }^{103}$ In case they see any infringement of the Regulation, competent authorities of the member states can exercise their powers and even suspend the issuer from trading in trading platforms or from issuing crypto-assets. ${ }^{104}$ Unfortunately, with a simple ex post review it is highly probable that these powers will be exercised only upon a consumer complaint.

The right of withdrawal is a specifically individual means of consumer protection, meaning that it can only be utilized by singular consumers and not collectively. Also, its efficiency can be contested since following the trade the crypto asset consumers will not be able to withdraw their consent and will have to rely on other, possibly less efficient methods for not sustaining losses.

\subsection{COMPLAINT HANDLING PROCEDURES}

Issuers of asset referenced tokens must have in place complaint handling procedures, ${ }^{105}$ the same obligation exists for service providers ${ }^{106}$ and competent authorities. ${ }^{107}$ While it is understandable that asset-referenced tokens carry the most possible danger to consumers, if complaint handling is an important measure for consumer precaution it is not quite clear why the other issuers are exempt from the duty to establish complaint handling procedures. What is more, for issuers of asset referenced tokens the complaint handling procedure carries so much weight that it is one of the requirements for authorization ${ }^{108}$ but issuers of generic crypto-assets do not have to follow such serious scrutiny.

It is uncontested that establishing complaint handling procedures is just the first step in ensuring that consumers can raise their voices, their effectiveness on the other hand is not easily measured and is hardly penalized by appropriate sanctions. An infringement of Article 27, regarding the complaint handling by asset referenced tokens issuers, can be punished by enforcing the issuance of a public statement about the incident, order to cease of the conduct, twice the profits earned by the act (which is obviously not the case) or $15 \%$ of the annual turnover. ${ }^{109}$ The latter penalty can seem discriminatively

100 Art. 12(4) of the Proposal.

101 Art. 12(5) of the Proposal.

102 Art. 5(1) c) of the Proposal.

103 Art. 11(4) of the Proposal.

104 Art. 82(1) of the Proposal.

105 Art. 27 of the Proposal.

106 Art. 64 of the Proposal.

107 Art. 91 of the Proposal.

108 Art. 16(2) o) of the Proposal.

109 Art. 92(3) a)-d) of the Proposal. 
harsh since not all issuers are subject of such penalties only issuers of asset-referenced tokens.

For service providers on the other side, infringement of Article $64^{110}$ regarding the establishment of complaint handling procedures can result in a public statement, an order to cease, a ban for the management body or other persons from exercising management functions, administrative fees of twice the benefits derived - which is once again not a relevant penalty, 500,000 euro fine or 5\% of annual turnover for legal persons or 500,000 euro fine for natural persons. ${ }^{111}$

Since white papers are not approved ex ante and there is no merit based scrutiny of white papers, complaint handling is of vital importance for the protection of consumers. Consequently, it is quite problematic that only a selected group of issuers is required to establish complaint handling measures and only they can be penalized for lacking in implementation.

\subsection{RULES ON CONFLICTS OF INTEREST}

Another obligation that applies to asset-referenced token issuers ${ }^{112}$ and crypto-asset service providers ${ }^{113}$ but not others is to establish rules on conflict of interest. While crypto-asset issuers, other than asset-referenced tokens and e-money tokens shall "prevent, identify, manage and disclose any conflicts of interest that may arise", 114 the issuers of asset-referenced tokens are given a precise obligation to follow the rules established in the Proposal to prevent, identify, manage (we can only wonder what managing conflict of interest means in this respect) and disclose conflicts of interest between themselves and shareholders, members of their management, employees, natural persons who own more than $20 \%$ share capital or voting rights and holders of their asset-referenced tokens. ${ }^{115}$ It is also not quite clear why the other type of issuers are not subjected to the same level of rigor.

Issuers of asset referenced tokens are also required to apply for authorization with a detailed description of their governance arrangements, ${ }^{116}$ another requirement specific to these categories of issuers. While it is understandable why governance arrangements should be disclosed for the benefit of closer scrutiny by competent authorities in case of conflicts of interest due to the holders of the reference asset, it would be a beneficial requirement for all issuers.

A possible danger to consumer protection is that issuers of asset referenced tokens have the opportunity to invest part of the reserve assets (the Proposal does not establish how that part is supposed to be measures or whether the whole reserve can be a part), but have the duty to only invest in "highly liquid

\footnotetext{
110 Art. 64 of the Proposal.

111 Art. 92(4) a)-f) of the Proposal.

112 Art. 28 of the Proposal.

113 Art. 65 of the Proposal.

114 Art. 13(1) c) of the Proposal.

115 Art. 28(1) of the Proposal.

116 Art. 16(1) of the Proposal.
} 
financial instruments with minimal market and credit risk." ${ }^{117}$ While profits or losses will be borne by the issuer, ${ }^{118}$ losses will effect consumers; thus the particularities of possible investment should be severely scrutinized. Conversely, the investment of funds received for e-money tokens must be invested "in assets denominated in the same currency as the one referenced by the e-money token". ${ }^{119}$

Similarly to the establishment of complaint handling procedures, establishing rules on conflicts of interest is more of a prudential requirement. However, truly avoiding conflicts of interest would be beneficial for consumers, who might be taken advantage of when conflicts are not disclosed. If undisclosed fraudulent conflicts remain undisclosed, consumers cannot be expected to defend themselves.

\subsection{INSIDER DEALING AND MARKET MANIPULATION}

Insider dealing, or insider trading as it is called in the United States, might not seem like an issue that is directly related to consumer protection. Insider dealing is the use of non-public information (for example information that has not been made public about a crypto-asset) for the benefit of the insider should be prevented in order to maintain the trust of consumers: if insiders have an advantage over consumers due to their insider knowledge, consumers will conclude that they are being taken advantage of and will not trust the market. Losing trust can be detrimental for financial markets, ${ }^{120}$ since following such a loss consumer will not use the market. It has been said by one leading Securities and Exchange Commission officer that fighting insider trading promotes investor confidence. ${ }^{121}$

Preventing insider dealing is crucial for the safety and trustworthiness of any financial market when we consider investor trust, and while crypto-assets are not mainly introduced into the European legislation as forms of investment, maintaining consumer trust in an increasingly conscious consumer environment should not be dismissed by European legislators. This is especially true since insider dealing is a precursor and is treated by the Proposal as a form of other market abuse practices (and can lead to market manipulation). ${ }^{122}$

Insider dealing is especially problematic when the assets that are subject of the insider information can be used as form of payment too - for example e-money tokens, and not just investment, as asset-referenced tokens can be. When consumers use crypto-assets, which are difficult technological and financial creations to begin with, and the issuers or service providers of these crypto-assets are hiding

117 Art. 34(1) of the Proposal.

118 Art. 34(3) of the Proposal.

119 Art. 49 of the Proposal.

120 Stout, L. A., 2009, Trust Behavior: The Essential Foundation of Securities Markets, SSRN Electronic Journal. doi: 10.2139/ssrn.1442023.

121 Remarks by Chairman Arthur Levitt U.S. Securities and Exchange Commission, 2020, A Question of Integrity: Promoting Investor Confidence by Fighting Insider Trading, February 27, 1998, "S.E.C. Speaks" Conference, (https://www.sec.gov/news/speech/speecharchive/1998/ spch202.txt, 10. 11. 2020).

122 Proposal, Title VI. 
some undisclosed and publicly not available information, loss of confidence from the public and even the eventual systemic risk will be unavoidable.

An example of investment endangering insider dealing in crypto-assets is provided via the fictitious story of Geekcoin's initial coin offering or ICO, similarly to an initial public offering of securities of primary markets. ${ }^{123}$ In Geekcoin insiders leveraged their inside information of the future ICO to trade Geekcoins on other exchanges. This increased trading could result in an increased valuation of the crypto-asset, while outsiders, who do not possess information about the ICO do not benefit. If similar situations would arise in relation to crypto-assets that are legal tender it would be no question that consumers would be understandably questioning the legitimacy of a highly fluctuating currency whose value can rise and fall over night if its issuer desires it to rise or fall. The Proposal seems to provide a clear cut prohibition to such endeavors, unlike the US SEC. ${ }^{124}$

Nevertheless, the Proposal lacks the necessary rigor when penalizing insider dealing. It requires competent authorities to enforce a permanent ban on the management body of the crypto-asset service provider, who engages in insider dealing or market manipulation. ${ }^{125}$ Unfortunately, not only the management level employees or service providers can come into possession of insider information, but lower level employees or issuers as well. If the administrative sanctions will only apply to the high level management categories, the cognizant prohibition will be fruitless, and consumers will possibly be in peril.

\subsubsection{Pump and Dump and Ponzi Schemes}

A special type of consumer abuse or price manipulation ${ }^{126}$ are the so-called pump and dumps, ${ }^{127}$ where the price and value of a crypto-asset is systematically increased by a collective buying of that crypto-asset, followed by the abrupt sale of that crypto-asset at the increased price. Their use is currently of never before seen proportions and often, pump and dump schemes are not even done secretly or unbeknownst to consumers. ${ }^{128}$ Taking advantage of the highly volatile nature of crypto-assets and of the effectiveness of buying crypto-assets in mass, the scammers are able to convince consumers that it is in their advantage to join in to the business of buying crypto-assets due to their rapid increase in value. This rapid increase is of course only due to the increased purchase of these assets done by the consumers themselves and is mainly beneficial to those who have

123 Anderson, J. P., 2019, Insider Trading and Crypto-assets: The Waters Just Got Muddier, Iowa Law Review Bulletin, 104, p. 121.

124 Ibid., p. 129.

125 Art. 92(6) f) of the Proposal.

126 Victor, F., Hagemann, T., 2019, Cryptocurrency Pump and Dump Schemes: Quantification and Detection. https://doi.org/10.1109/ICDMW.2019.00045.

127 Jensen, P. M., Uhlig, S., 2020, Draft regulation on markets in crypto-assets: end of the crypto-asset "pump and dump" and Ponzi-schemes? Lexology, (https://www.lexology.com/library/ detail.aspx?g=6b5295a1-caff-4880-94a7-139a3f76af2d, 11. 11. 2020).

128 Dhawan, A., Putniňš, T. J., 2020, A New Wolf in Town? Pump-and-Dump Manipulation in Cryptocurrency Markets, SSRN Scholarly Paper No. ID 3670714, (https://doi.org/10.2139/ ssrn.3670714). 
contributed to the increased price rise if they can sell the crypto-assets at their high price, while those who would buy the crypto-assets after they have been dumped would already buy them on their decreased value and at a loss. Due to the increased demand for crypto-assets during the blowing up phase if a big amount of those crypto-assets gets sold at once the price of the remaining assets will decrease, leading to some consumers terrible losses. ${ }^{129}$

Naturally, easily manipulating the prices of crypto-assets which can be used as legal tender, or for investments even, is against all possible consumer protection ideals. Both these methods rely on creating a community of consumers who purchase a large amount of crypto-assets in order to blow up the price. Similarly, it would be of vital importance that the same community of wronged consumers be able to enforce their interests against the scammers via collective consumer protection measures.

A similarly structured overvalued sale can be achieved with the combination of the "traditional" Ponzi scheme method, where crypto-asset buyers' new investment pays for the former holders. It is often that Ponzi schemes employ the active recruitment of new holders to thus raise the price of the crypto-assets. Ponzi schemes have been rightly considered to be "fraudulent chameleons of finance", due to all the different and novel forms they can present themselves to the public. ${ }^{130}$

There are several examples of crypto-asset Ponzi schemes in the United States. For example in SEC v. Shavers, ${ }^{131}$ old Bitcoin investors were paid by diverting the Bitcoins that new investors provided to Shavers. ${ }^{132}$ There is also the example of the currently developing OneCoin fiasco. ${ }^{133}$ But it is also possible to find European examples ${ }^{134}$ - which gives a reason to the European legislator to specifically have this danger in mind when finalizing the Regulation.

\section{CONCLUSIONS. HOW CAN WE BETTER PROTECT CONSUMERS?}

The regulation of crypto-assets is of paramount importance in the EU because more and more Europeans turn to crypto-assets mostly for investment purposes but in the future some may want to, or will be forced to, use cryp-

129 Hamrick, J.T. et al., 2018, The Economics of Cryptocurrency Pump and Dump Schemes, SSRN Electronic Journal, 10.2139/ssrn.3303365.

130 Tajti, T., 2019, Pyramid and Ponzi Schemes and the Price of Inadequate Regulatory Responses: A Comparative Account of the Diverging Regulatory Responses of China, Europe, and the United States, Texas Tech Business and Bankruptcy Law Journal, 5, p. 38.

131 SEC v. Shavers, No. 4:13-cv-416, 2013 WL 4028182.

132 Trendon T. Shavers and Bitcoin Savings and Trust, 2014, Release No. LR-23090; September 22, 2014, (https://www.sec.gov/litigation/litreleases/2014/lr23090.htm, 14. 11. 2020).

133 Hope, K., 2019, Crypto scam offers modern twist on classic pyramid fraud. Financial Times, (https://www.ft.com/content/b5a45880-0bad-11ea-8fb7-8fcec0c3b0f9, 14. 11. 2020).

134 Erazo, F., 2020, Alleged crypto Ponzi scheme targeting Spanish speakers freezes user funds, Cointelegraph, (https://cointelegraph.com/news/alleged-crypto-ponzi-scheme-targeting-spanish-speakers-freezes-user-funds, 14. 11. 2020). 
to-assets as a means of exchange for goods and services. The Proposal puts forward registration and disclosure obligations, a possibility to withdraw from the agreement, the requirement of establishing complaint handling mechanisms and rules on conflicts of interest and insider dealing for the benefit of the European consumers. However, all these measures seem to suffer from two deficiencies. On the one hand they will hardly be efficient in protecting consumers, on the other hand they seem to employ unnecessary discrimination against some issuers, namely issuers of asset-referenced tokens, but not against others.

The main methods employed by the Proposal are disclosure measures and ex post review and intervention. As a first step for protecting consumers, the place of registration of the issuers and service providers are categorized differently according to what types of crypto-assets they are issuing or services they provide, with some issuers having the possibility to be active in the EU without having their place of registration in any member state, while others, issuers of asset-referenced tokens and e-money tokens, only if registered in the EU. This allows for broader supervisory possibilities in case of the former. The proposal imposes white paper obligations together with disclosure of the complaint handling procedure and rules on conflicts. The Proposal also provides provisions against market abuse and price abuse - two issues that are increasingly prevalent in the crypto-asset business.

The main problem with the Proposal can be summarized in three points:

1) The Proposal relies heavily on disclosure obligations which are meant to inform the layman consumer about the dangers involved in crypto-assets, mainly via the obligation to draft, notify and publish a white paper by the issuers. While this is a first step in informing consumers, the fact that there is no ex ante approval of the white papers, it is highly probable that the information provided there will not be enough to effectively warn and inform consumers.

2) There is a heavy incongruence between the treatment of some issuers and others, while service providers are mainly treated equally. The difference of treatment for issuers of asset-referenced tokens and e-money tokens is explained by the fact that their crypto-assets can pose a more possible threat to consumers, however, this treatment encourages issuers to only issue generic crypto-assets, which escape a most of the rigorous regulation that the issuers of asset-referenced tokens and e-money tokens cannot. Other types of crypto-assets should not be treated as less of a threat, these can just as well lead to price manipulation (in fact even more so, since they are not based on any reserve of assets) or other consumer abuse.

3) The provisions of the Proposal rely on individual consumers initiating actions against issuers or service providers, for example the right of withdrawal is exactly one such provision. It would be advisable for the final version of the Regulation to include references to collective consumer protection measures. Collectively acting against issuers or service providers can have a more deterrent effect due to the enlarged 
pool of complaints that will strike at once. With collective actions the holders of crypto-assets that have lost their value due to price manipulation can enforce their rights against the manipulators in an efficient manner.

Including collective consumer protection measures in the Regulation would be especially advised since the Directive regarding possible representative collective consumer protection possibilities is still far away from providing protection to consumers equally in all member states in the European Union. If the European legislator intends to provide protection to its citizens, collective consumer protection measures must be employed.

\section{BIBLIOGRAPHY}

1. Anderson, J. P., 2019, Insider Trading and Crypto-assets: The Waters Just Got Muddier, Iowa Law Review Bulletin, 104.

2. Dhawan, A., Putniņš, T. J., 2020, A New Wolf in Town? Pump-and-Dump Manipulation in Cryptocurrency Markets, SSRN Scholarly Paper No. ID 3670714, (https://doi. org/10.2139/ssrn.3670714).

3. ECB, 2020, Report on a Digital Euro 55 October 2020, (https://www.ecb.europa.eu/ pub/pdf/other/Report_on_a_digital_euro 4d7268b458.en.pdf, 13. 11. 2020).

4. Hamrick, J. T. et al., 2018, The Economics of Cryptocurrency Pump and Dump Schemes, SSRN Electronic Journal, 10.2139/ssrn.3303365.

5. Houben, R., Snyers, A., 2020, Crypto-assets - Key Developments, Regulatory Concerns and Responses, Study for the Committee on Economic and Monetary Affairs, Policy Department for Economic, Scientific and Quality of Life Policies, European Parliament, Luxembourg, PE 648.779.

6. Jensen, P. M., Uhlig, S., 2020, Draft regulation on markets in crypto-assets: end of the crypto-asset "pump and dump" and Ponzi-schemes? Lexology, (https://www.lexology. com/library/detail.aspx?g=6b5295a1-caff-4880-94a7-139a3f76af2d, 11. 11. 2020).

7. OECD, 2020, The Tokenisation of Assets and Potential Implications for Financial Markets, OECD Blockchain Policy Series, (www.oecd.org/finance/The-Tokenisation-ofAssets-and-PotentialImplications-for-Financial-Markets.html, 13. 11. 2020).

8. Stout, L. A., 2009, Trust Behavior: The Essential Foundation of Securities Markets, SSRN Electronic Journal. doi: 10.2139/ssrn.1442023.

9. Tajti, T., 2019, Pyramid and Ponzi Schemes and the Price of Inadequate Regulatory Responses: A Comparative Account of the Diverging Regulatory Responses of China, Europe, and the United States, 5 Texas Tech Business and Bankruptcy Law Journal.

10. Tajti, T., Fintech Regulation in Hungary, in: Cian, M., Sandei, C. (eds.), 2020, Diritto del Fintech. $1^{\text {st }}$ ed. Milano, Wolters Kluwer Italy - CEDAM.

\section{LEGISLATIVE ACTS}

1. Act on the Implementation of the Amendment Directive to the Fourth EU Money Laundering Directive, Entwurf eines Gesetzes zur Umsetzung der Änderungsrichtlinie zur Vierten EU-Geldwäscherichtlinie [Richtlinie (EU) 2018/843]. 
2. Proposal for a Directive of the European Parliament and of the Council on the representative actions for the protection of the collective interests of consumers, and repealing Directive 2009/22/EC COM/2018/0184 final - 2018/089.

3. Proposal for a Regulation of the European Parliament and of the Council on Markets in Crypto-assets, and amending Directive (EU) 2019/1937, COM/2020/593.

4. Regulation (EU) 2017/1129 of the European Parliament and of the Council of 14 June 2017 on the prospectus to be published when securities are offered to the public or admitted to trading on a regulated market, and repealing Directive 2003/71/EC.

5. Regulation (EU) 1215/2012 of the European Parliament and of the Council on jurisdiction and the recognition and enforcement of judgments in civil and commercial matters (recast) (Recast Brussels Regulation).

6. The Loi PACTE Act no. 2019-486. Official Journal, May 23, 2019.

7. Virtual Financial Assets Act, Cap. 590 of the Laws of Malta, 2018.

\section{CASE LAW}

1. SEC v. Shavers, No. 4:13-cv-416, 2013 WL 4028182.

\section{INTERNET SOURCES}

1. Edwards, J., 2020, Bitcoin's Price History, Investopedia, (https://www.investopedia. com/Art.s/forex/121815/bitcoins-price-history.asp, 13. 11. 2020).

2. Erazo, F., 2020, Alleged crypto Ponzi scheme targeting Spanish speakers freezes user funds, Cointelegraph, (https://cointelegraph.com/news/alleged-crypto-ponzi-scheme-targeting-spanish-speakers-freezes-user-funds, 14. 11. 2020).

3. ESMA, Who we are, (https://www.esma.europa.eu/about-esma/who-we-are, 12. 11. 2020).

4. European Banking Authority, 2016, European Union, (https://europa.eu/europeanunion/about-eu/agencies/eba_en, 12. 11.2020).

5. Hayes, A., Stablecoin, Investopedia, (https://www.investopedia.com/terms/s/stablecoin.asp, 14. 11. 2020).

6. Hope, K., 2019, Crypto scam offers modern twist on classic pyramid fraud, Financial Times, (https://www.ft.com/content/b5a45880-0bad-11ea-8fb7-8fcec0c3b0f9, 14. 11. 2020).

7. INCE Group, 2020, Cryptoassets - Believing the money laundering impact, (https:// www.incegd.com/en/news-insights/cryptoassets-believing-money-laundering-impact, 11. 11. 2020).

8. Redman, J., 2020, ICO Crackdown, 11 Class-Action Lawsuits Filed Against Cryptocurrency Companies, Bitcoin News, (https://news.bitcoin.com/ico-crackdown-11-classaction-lawsuits-filed-against-cryptocurrency-companies/, 11. 11. 2020).

9. Remarks by Chairman Arthur Levitt U.S. Securities and Exchange Commission, 2020, A Question of Integrity: Promoting Investor Confidence by Fighting Insider Trading, February 27, 1998, "S.E.C. Speaks" Conference, (https://www.sec.gov/news/ speech/speecharchive/1998/spch202.txt, 10. 11. 2020).

10. Sharma, T. K., 2019, Security Tokens vs. Utility Tokens: A Concise Guide, Blockchain Council, (https://www.blockchain-council.org/blockchain/security-tokens-vs-utilitytokens-a-concise-guide/, 12. 11. 2020). 
11. Spending BitCoin, (https://bitcoin.org/en/spend-bitcoin, 13. 11. 2020)

12. Trendon T. Shavers and Bitcoin Savings and Trust, 2014, Release No. LR-23090; September 22, 2014, (https://www.sec.gov/litigation/litreleases/2014/lr23090.htm, 14. 11. 2020).

13. Victor, F., Hagemann, T., 2019, Cryptocurrency Pump and Dump Schemes: Quantification and Detection, (https://doi.org/10.1109/ICDMW.2019.00045).

\title{
ZAŠTITA POTROŠAČA PREDVIĐENA PREDLOGOM PROPISA ZA UREĐENJE TRŽIŠTA KRIPTOVALUTA
}

\author{
Ágnes Horváth
}

\section{REZIME}

Ovaj rad bavi se Predlogom propisa Evropskog parlamenta i Saveta za tržišta kriptoimovine (u daljem tekstu: MiCA) ${ }^{135}$ i izmenom Direktive (EU) 2019/1937 o zaštiti lica koja prijave kršenje zakona Unije, što predstavlja dugoočekivani propis u oblasti kriptoimovine za sve države članice Evropske unije. Rad analizira koje su implikacije Predloga za evropske potrošače i zakone o zaštiti potrošača kao oblasti u Evropskoj uniji (u daljem tekstu: EU). Sve rasprostranjenija upotreba kriptoimovine u različite svrhe i nepostojanje propisa o kriptoimovini stvorili su probleme koje Predlog namerava da reši, uključujući propise o različitim vrstama kriptoimovine, na primer o tokenima e-novca i takozvanim stabilnim novčićima (engl. stablecoins) ili tokenima koji se pozivaju na drugu imovinu (engl. asset-referenced tokens), kao i propise o aktivnostima izdavalaca kriptoimovine $\mathrm{i}$ pružalaca usluga kriptoimovine. Pitanje kriptoimovine predstavlja naročito problematičnu temu potencijalnih regulatornih mera zato što je kriptoimovina prvobitno osmišljena kao imovina koja treba da zaobiđe propise, istorijski se oslanjala na tehnologiju decentralizovanih distribuiranih glavnih knjiga, što omogućava stvaranje vrednosti bez uključivanja državnih vlasti ili banaka, uz oslanjanje samo na računarske algoritme. Predlog namerava da spreči nepoštene i nesmotrene aktivnosti koje su bile moguće zbog nepostojanja propisa. Regulisanje ove vrste sve rasprostranjenije imovine može se posmatrati kao krajnje neophodno u društvu koje je na ivici ekonomskog zastoja i krize usled pandemije.

Direktne ciljne grupe Predloga su pružaoci usluga kriptoimovine i izdavaoci kriptoimovine. Predlog pokušava da ustanovi pravila i mere zaštite potrošača u cilju onemogućavanja pokušaja zloupotrebe na tržištu. Predlog definiše šta su usluge kriptoimovine i šta pružaoci usluga kriptoimovine mogu da ponude klijentima koji, kao i u svakoj drugoj oblasti zaštite potrošača, moraju da budu zaštićeni na odgovarajući način. Predlog predviđa nove obaveze za organe na nivou država i EU (naročito za Evropsku bankarsku upravu, odnosno EBA i Evropsku upravu za obveznice i berze ili ESMA), što obuhvata i osnivanje „kompetentnih uprava“. Predlog takođe predviđa obaveze obaveštavanja za države članice, kao i administrativne sankcije ili mere.

Ovaj rad u kratkim crtama predstavlja ključne tačke Predloga u vezi sa zaštitom potrošača i bavi se posebnim pravilima zaštite potrošača. Pokušava da ustanovi da li Predlog

135 Predlog propisa Evropskog parlamenta i Saveta za tržišta kriptoimovine i izmena Direktive (EU) 2019/1937 (u daljem tekstu: Predlog). Ovaj rad bavi se verzijom Predloga koja je objavljena 24. 9. 2020. 
pruža kolektivna prava u cilju efektivnije zaštite potrošača. Nakon analize zaštitnih mera koje Predlog sadrži u cilju zaštite potrošača, u radu su navedeni predlozi kako da se efikasnije zaštite evropski potrošači. U prvom poglavlju opisane su definicije. Ukratko je objašnjeno koje su različite vrste kriptoimovine: kako tokeni koji se pozivaju na drugu imovinu i tokeni e-novca predstavljaju različite potklase šire kriptoimovine. Ovaj pregled je neophodan da bi se razumele potencijalne opasnosti koje različite vrste kriptoimovine predstavljaju za potrošače.

U drugom poglavlju su prikazana lica na koja se propisi odnose, pre svega izdavaoci kripto-imovine i pružaoci usluga kriptoimovine. Takođe, pojasnili smo koji su organi Evropske unije uključeni u regulatorni proces, ESMA, odnosno Evropska uprava za obveznice i berze i EBA ili Evropska bankarska uprava. Prikaz izdavalaca i pružalaca usluga pomoći će nam da razumemo vrste aktivnosti koje predstavljaju opasnost za potrošače. Treće poglavlje usredsređeno je na mere zaštite potrošača obuhvaćene Predlogom, sa specifičnim ciljem ustanovljavanja kolektivnih oblika zaštite. Bavi se obavezama belih knjiga kriptoimovine, pravom povlačenja sredstava, procesom rešavanja žalbi, pravilima o sukobu interesa i insajderskom trgovanju i manipulaciji tržišta. U poslednjem poglavlju izneti su zaključci rada i navedeni su mogući predlozi za unapređenje konačnog oblika propisa.

Ključne reči: kriptoimovina, izdavaoci kriptoimovine, pružaoci usluga kriptoimovine, EBA, ESMA, Evropska unija, zaštita potrošača. 